\title{
The Role of Cycling in Sustainable Urban Life: Perception of Cyclists in Turkey
}

\author{
Senem Ceyiz ${ }^{1}$ \\ ${ }^{1}$ Kastamonu University School of Physical Education and Sport, Kastamonu, Turkey \\ Correspondence: Senem Ceyiz, Kastamonu University School of Physical Education and Sport, Kuzeykent \\ Campus, Kastamonu, Turkey. E-mail: sceyiz@kastamonu.edu.tr
}

Received: November 23, 2019

Accepted: December 20, 2019 Online Published: December 31, 2019

doi:10.5539/jel.v9n1p60

URL: https://doi.org/10.5539/jel.v9n1p60

\begin{abstract}
The aim of this study was to determine the perceptions of bicyclists to promote the use of bicycles in the cities. The sample was selected using simple random sampling method. A total of 1087 bicyclists, including 178 women and 909 men, who used bicycles in their everyday lives in the city, voluntarily participated in the research. The study was a descriptive research in the survey model and quantitative research approach was adopted in the research. Data were collected with "Bike Use Dissemination Scale" developed by Çeyiz (2019). The scale consists of two parts; a personal information form and expressions of participants' dissemination of bicycle use. The t-test was used for the variables consisting of the bipartite groups and the One-Way ANOVA was used for the variables consisting of more than two groups. According to the data obtained from the bicyclists participating in the survey, there was a significant difference in the dimensions of security and dissemination by gender. It was found that women bicyclists' safety perceptions were more negative than men's perception; and their perceptions of the spreading dimension were more positive than the male bicyclists.
\end{abstract}

Keywords: bicyclist, sustainability, promoting the use of bicycles

\section{Introduction}

The rapid development of technology forces people to live their everyday and work life almost inactively. It is a fact that with many things demanding on our limited time, individuals have difficulty to make time for physical activities. In this respect, using bicycles is a unique means that offers both transport facilities and physical activity benefits at the same time. Although for many individuals cycling doesn't go further than being childhood memories, for some part of the society whose number is on the increase day by day cycling is sometimes a transportation vehicle and sometimes a means of creative activities as well.

In addition to the positive effects of cycling on individual issues such as public health, it is known that it also provides many benefits in environmental issues. Using bicycles provide positive spiritual and physical gains such as increasing cardiovascular performance (Hendriksen, Zuiderveld, Kemper, \& Bezemer, 2000), positive human relations (O'connor \& Brown, 2007), self esteem (Garrard, Rose, \& Lo, 2008). Healthy individuals contribute to the development of countries by bringing about healthy society outputs. For this reason, societies with concerns such as community health and quality life tend to find solutions by encouraging individuals to use bicycles (Krizek, Poindexter, Barnes, \& Mogush, 2007).

When it comes to the concept of "sustainability", the bicycle takes its place at the center of the subject. Many words cited with this concept (Sustainable transport, urban sustainability, environmental sustainability, sustainable physical activity, etc.) are directly or indirectly related to the use of bicycles. Bicycle is both a symbol and a tool for maintaning the environmental struggle (Horton, 2006).

\section{Review of Literature}

\subsection{Cycling in Terms of Urban Sustainability and Transportation}

The use of bicycles for transportation is important in terms of urban sustainability. Widespread use of bicycles helps to minimize transportation costs, air and noise pollution, traffic accidents, traffic congestion and the negative effects of climate change (Bauman et al., 2008). Cycling is an effective means of transport in reducing the need for non-renewable energy sources and ensuring environmental sustainability (Mert \& Öcalır, 2010). 
It is a means of transportation that contributes to the solution of traffic congestion and pollution problems caused by motor vehicle traffic especially in the cities of developed countries. In European countries, such as the Netherlands, Denmark and Germany, where daily transport rates are achieved by bicycle rather than cars, the rate of carbon emissions per capita in passenger transport is reported to be lower than in the United States (International Energy Agency). Figure 1 shows cycling and walking rates in the respective countries (Buehler \& Pucher, 2012).

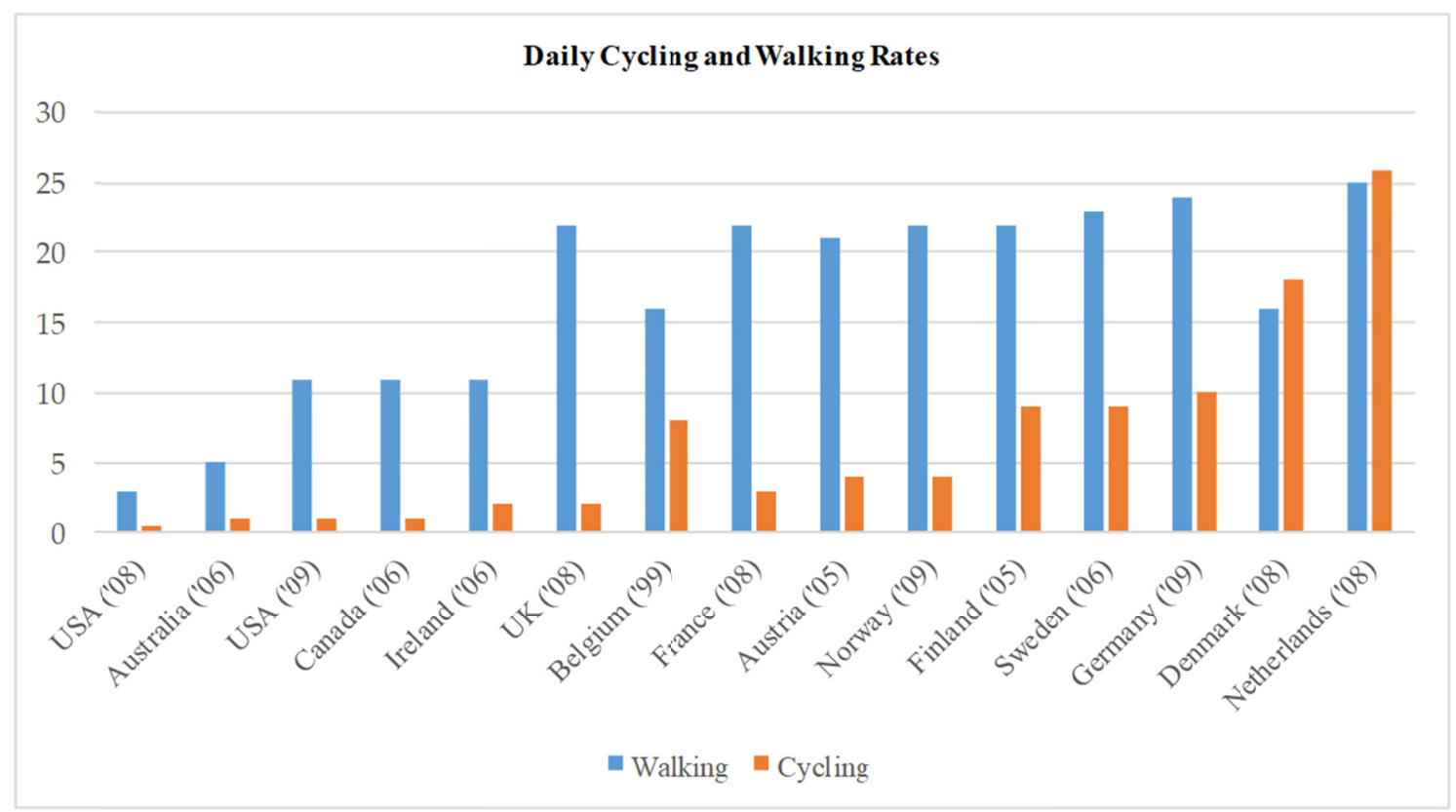

Figure 1. The ratio of cycling and walking in Europe, North America and Australia 1999-2009

Source. Buehler and Pucher, 2012.

As for Turkey, according to official statistics the number of motor vehicles has been increasing rapidly every year (Türkiye İstatistik Kurumu). The relevant statistics are shown in the Figure 2.

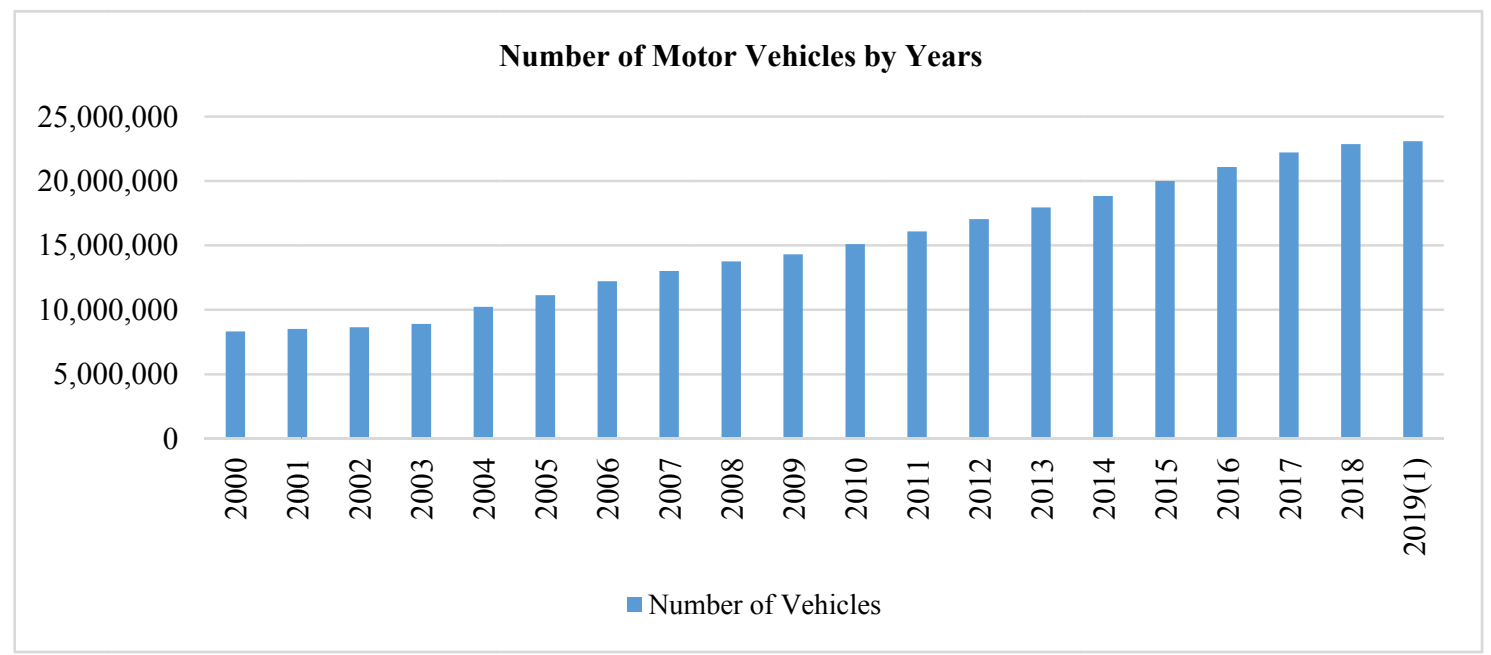

Figure 2. Number of Motor Vehicles by Years in Turkey

Source: Türkiye İstatistik Kurumu. (1) Data as of the end of July. 
Contrary to this figure, in terms of users' direct expenditures and public infrastructure investments, promoting cycling, which is less costly than private vehicle or public transport (Buehler, \& Pucher, 2012) is considered to be a necessity in terms of urban sustainability.

Risks encountered by cycling individuals, perceived and actual risk levels were investigated by assessing and it was found that individuals were motivated to ride as long as they felt safe in traffic (Bauman et al., 2008). When cycling mortality and non-fatal injury rates between 2004 and 2009 are examined in the Netherlands, Denmark, Germany, the United Kingdom and the United States, (Figure 3), it is seen that the bicycle infrastructure is prioritized and therefore the accident rates are low in countries with high cycling rates (Buehler \& Pucher, 2012).

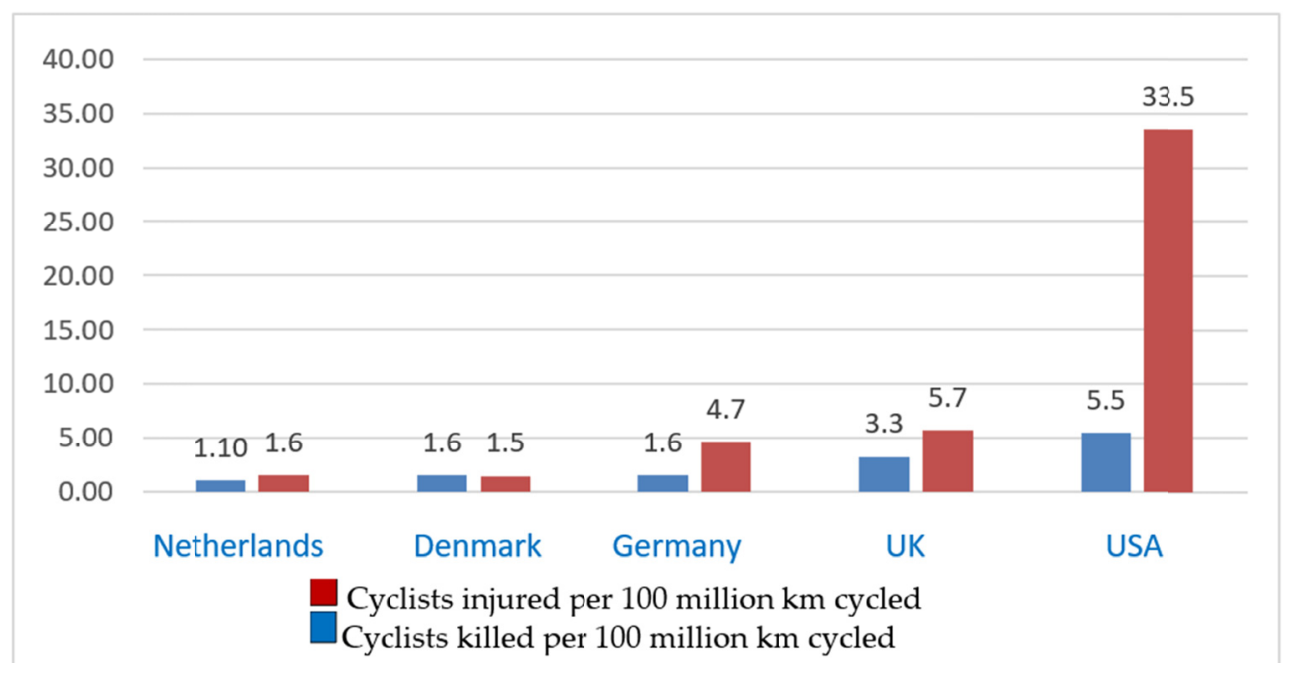

Figure 3. Deaths and causalities per km (between the years 2004-2009)

Source: Buehler and Pucher, 2012.

The most common factors that leads cyclists to violate the road rules are poor infrastructure design, followed by motorized traffic speed and the behavior of other road users, respectively (Shaw, Poulos, Hatfield, \& Rissel, 2015). In this case, it can be said that the formation of the infrastructure for the use of bicycles brought the result of the cyclist to travel safely in traffic.

\subsection{Infrastructure Requirements for Sustainable Bicycle Transportation}

It does not seem possible to solve the transport problem in cities rapidly transforming into metropolitans with a motor vehicle-oriented perspective. For sustainable transportation in cities, it seems inevitable to reduce the share of motor vehicles in transportation and increase the percentage of public transportation and non-motorized transportation types (bicycle and pedestrian) (Cirit, 2014).

It is thought that some planning and regulations regarding the flow of traffic are necessary for the bicycle to be adopted by individuals as a means of transportation in urban life. When the practices performed worldwide are examined, integration into public transport, bicycle stations, bicycle lanes, other facilitators and necessary traffic arrangements are among the highlights of these practices.

\subsection{Integration of Bicycle to Public Transport}

Cycling is an instrument that allows the individual to travel with his or her physical strength; as a consequence of this, travel distance is an important factor affecting the use of bicycles. Average bicycle travel density in Turkey is seen to be an average of 10-15 km/h and between 20-30 minutes (about 5-8 km) (Uz \& Karaşahin, 2004). In order to reach further distances by bicycle, enabling cyclists to travel with their bicycles on public transport facilities is one of the motivating practices that can increase the use of bicycles in society. Public transport station designs should provide safe, convenient and comfortable cycling at both stations and on-road stops (Buehler \& Pucher, 2012).

There are many systems and mechanisms for transporting bicycles on public transport. In addition to the 
mechanisms to which bicycles can be attached horizontally or vertically with hooks or straps in the vehicles, a separate trailer attached to the outside of the vehicle (front or rear) is also among the applications (Give Cycling A Push, 2010).

The practices coordinating public transport and bicycle can be divided into four main categories (Pucher, \& Buehler, 2008).

- Secure bicycle parking areas at railway stations and bus stops.

- The divisions on trains and buses where bikes can be placed.

- Bicycle rental stations located close to public transport stops.

- Coordination of public transport and bicycle paths.

\subsection{Bicycle Stations, Bicycle Routes and Parking Spaces}

In order to encourage individuals to use bicycles in their daily life, primarily, it is necessary to make the bike rider feel safe in traffic. The bike path or lane is a designated area for the access of bicyclists, with road signs and possibly colored or bicycle logos, where the passage or parking of motor vehicles is prohibited (Give Cycling A Push, 2010).

The bicycle sharing system/station is one of the practices that promote the use of bicycles in the city, providing individuals using bicycles as a form of public transport (Lin, Yang, \& Chang, 2013; Lin \& Yang, 2011). Bicycle sharing systems play an important role in increasing sustainable transportation options in cities (O'brien, Cheshire, \& Batty, 2013). Bicycle rental stations, which can be located in different parts of the city by local authorities, promote wider use of bicycles. In this sense, numerical data of some countries and cities performing infrastructure studies for bicycle paths and stations are shown in the Table 1 (Midgley, 2011).

Table 1. The Number of Bicycle Lanes and Stations

\begin{tabular}{lllll}
\hline Country & City & Number of Bicycle Stations & Number of Bikes Per Station & Bicycle Path (km) \\
\hline Brazil & Rio de Janeiro & 250 & 19 & 140 \\
Canada & Montreal & 5000 & 400 & 600 \\
Italy & Milan & 1400 & 104 & 123 \\
France & Lyon & 4000 & 343 & 265 \\
Rep. Of Korea & Daejeon & 224 & 18 & 192 \\
Norway & Oslo & 1200 & 120 & 250 \\
Poland & Krakow & 155 & 13 & 99 \\
Spain & Barcelona & 6000 & 400 & 177 \\
Sweden & Stockholm & 2000 & 180 & 760 \\
England & Reading & 21 & 3 & 60 \\
The USA & Denver & 500 & 50 & 160 \\
\hline
\end{tabular}

Source. Midgley, 2011.

The availability of secure bicycle parking spaces at certain points of the city and in places such as shopping malls is just as important as the cycling network for widespread use of bicycles. If individuals can park their bikes in the city center without worrying about the theft of their bikes, they can travel by bicycle without hesitation (Give Cycling A Push, 2010).

\section{Method}

\subsection{Purpose of the Study}

The aim of the study was to determine the perceptions of bicyclists to promote the use of bicycle focused on sustainable urban life.

\subsection{Research Model}

The study is descriptive in the survey model. Quantitative research approach was adopted in the research.

\subsection{Research Group}

The study population are individuals who regularly use bicycle in their daily life in Turkey. The sample of the study consists of 1087 bicyclist determined by simple random sampling method.

\subsection{Data Collection Tool}

In the research, "Bike Use Dissemination Scale" (BUDS) developed by Çeyiz (2019) and "Personal Information 
Form" prepared by the researcher for this research were used. BUDS consists of 24 items which is likert type and scored from 1 to 5 and and 3 sub-dimensions (benefit, dissemination, security). The high score obtained from the sub-dimensions of the scale indicates high perception and the low score indicates low perception. The highest and lowest scores that can be obtained from the sub-dimensions of the scale are; the highest is 65 points, the lowest is 13 points for the dimension of "Benefit", the highest is 35 points, the lowest is 7 points for the dimension of "Dissemination", the highest is 20 points, the lowest is 4 points for the dimension of "Security". Items of the dimension of "safety" are reverse coded items.

As a result of the reliability analysis conducted in this study, the internal consistency coefficients of the overall scale and its sub-dimensions are shown in the Table 2.

Table 2. Internal consistency coefficient of BUDS

\begin{tabular}{ll}
\hline & Cronbach's Alpha (Cr $\boldsymbol{\mu})$ \\
\hline Internal Consistency Coefficient of The Whole BUDS & .840 \\
Internal Consistency Coefficient of The Dimension Of "Benefit" & .815 \\
Internal Consistency Coefficient of The Dimension Of "Security" & .865 \\
Internal Consistency Coefficient of The Dimension Of "Dissemination" & .717 \\
\cline { 2 - 2 }
\end{tabular}

Cronbach's Alpha between "0.60-0.79 indicates that the scale is "reliable" and Cronbach's Alpha between "0.80-1.00" indicates that the scale is "highly reliable" (Tezbaşaran, 1997). According to the results of the reliability analysis, the scale was found to be usable.

\subsection{Data Collection}

Data was collected electronically through the social media accounts of bicyclists.

\subsection{Data Analysis}

For the purposes of the study, the arithmetic means and standard deviations of the scores obtained by the bicyclists from the sub-dimensions of the scale were calculated.

It was investigated whether the scores obtained from the sub-dimensions of the participants differed according to their personal information (gender, marital status, income status, education, age, how many years has been cycling). Normal distribution analysis of the data was performed by Skewness and Kurtosis values analysis. Skewness and Kurtosis values of the sub-dimensions of the scale are shown in the Table 3.

Table 3. Skewness and Kurtosis of the data

\begin{tabular}{lll}
\hline Sub Dimensions & Skewness & Kurtosis \\
\hline Security & 1.122 & .967 \\
Benefit & -1.623 & 5.023 \\
Dissemination & -1.560 & 4.245 \\
\hline
\end{tabular}

Source. own study.

Data with skewness values between $-2 /+2$ and kurtosis values between $-7 /+7$ show normal distribution (Byrne, 2010). Parametric tests were applied to data showing normal distribution. In independent samples, t-test was used to compare the two groups; One-way analysis of variance (ANOVA) was used to compare more than two groups.

\section{Results}

Demographic information of the bicyclists participating in the research is shown in the Table 4. 
Table 4. Demographic information of the bicyclists

\begin{tabular}{|c|c|c|c|}
\hline Demographic İnformation & Groups & $f$ & $\%$ \\
\hline \multirow[t]{2}{*}{ Gender } & Male & 909 & 83.6 \\
\hline & Female & 178 & 16.4 \\
\hline \multirow[t]{2}{*}{ Marital status } & Married & 383 & 35.2 \\
\hline & Single & 704 & 64.8 \\
\hline \multirow[t]{5}{*}{ Age } & $18-23$ years old & 306 & 28.2 \\
\hline & 24-29 years old & 231 & 21.3 \\
\hline & $30-35$ years old & 190 & 17.5 \\
\hline & $36-40$ years old & 121 & 11.1 \\
\hline & 41 years and older & 239 & 22.0 \\
\hline \multirow[t]{4}{*}{ Education } & Primary-Secondary School Graduate & 51 & 4.7 \\
\hline & High School Graduate & 350 & 32.2 \\
\hline & Bachelor's Degree & 602 & 55.4 \\
\hline & Postgraduate & 84 & 7.7 \\
\hline \multirow[t]{6}{*}{ Income status } & $0-1300 \mathrm{TL}$ & 360 & 33.1 \\
\hline & $1301-1800 \mathrm{TL}$ & 167 & 15.4 \\
\hline & $1801-2700 \mathrm{TL}$ & 196 & 18.0 \\
\hline & $2701-3400 \mathrm{TL}$ & 133 & 12.2 \\
\hline & $3401-4300 \mathrm{TL}$ & 93 & 8.6 \\
\hline & 4301 and over & 138 & 12.7 \\
\hline \multirow[t]{4}{*}{ Actively Cycling } & Less than 1 year & 154 & 14.2 \\
\hline & $1-3$ years & 330 & 30.4 \\
\hline & 4-6 years & 153 & 14.1 \\
\hline & More than 6 years & 450 & 41.4 \\
\hline Total & & 1087 & 100.0 \\
\hline
\end{tabular}

Source. own study.

The mean scores of the participants' sub-dimensions of the scale are shown in the Table 5.

Table 5. Distribution of mean scores of bicyclists from sub-dimensions of the scale

\begin{tabular}{llll}
\cline { 2 - 4 } Dimensions & $\overline{\boldsymbol{X}} \pm \boldsymbol{s \boldsymbol { s }}$ & Minimum & Maksimum \\
\cline { 2 - 4 } Security (n:1087) & $1.83 \pm 0.83$ & 1.00 & 5.00 \\
Benefit (n:1087) & $4.57 \pm 0.40$ & 1.62 & 5.00 \\
Dissemination (n:1087) & $4.51 \pm 0.48$ & 1.00 & 5.00 \\
\hline
\end{tabular}

Source. own study.

According to the arithmetic mean of the scores obtained from the sub-dimensions of the scale; the perceptions of the participants were low in the security sub-dimension, (Mean: 1.83, Standard Deviation: 0.83). In the sub-dimensions of benefit and dissemination, the perceptions of the participants were found to be high (Benefit; Mean $=4.57$, Standard Deviation: 0.40, Dissemination; Mean: 4.51, Standard Deviation: 0.48). These findings indicate that participants' perception of safety during cycling is low. In addition, it was concluded that the perceptions of the participants were high in terms of the benefits obtained from regular cycling and the spread of cycling in the society.

The mean scores of the participants' sub-dimensions of the scale according to their gender are shown in the Table 6.

Table 6. T-test results according to gender of bicyclists

\begin{tabular}{llllll}
\hline Dimensions & Gruplar & $\overline{\boldsymbol{X}} \pm$ ss & sd & t & p \\
\hline Security & Male (n:909) & $1.86 \pm 0.841 .71 \pm 0.78$ & 1085 & 2.06 & $0.31^{*}$ \\
& Female (n:178) & & & \\
Benefit & Male (n:909) & $4.56 \pm 0.394 .57 \pm 0.44$ & 0.29 & 0.76 \\
& Female (n:178) & & & $0.31^{*}$ \\
\multirow{2}{*}{ Dissemination } & Male (n:909) & $4.49 \pm 0.484 .58 \pm 0.48$ & & 2.16 & \\
\hline
\end{tabular}

Source. own study, ${ }^{*} \mathrm{p}<0.05$. 
According to the Table 6, a significant difference was found in the scores of the bicyclists from the sub-dimensions of security and dissemination according to gender (Security: $t=2.06, p<0.05$; Dissemination: $t=2.16, p<0.05$ ). It is seen that the safety scores of female bicyclists $(1.71 \pm 0.78)$ are lower than that of male bicyclists $(1.86 \pm 0.84)$. Therefore, it was found that the "Safety" perception of female bicyclists was lower than that of male bicyclists. In the "Dissemination" sub-dimension, the scores of female bicyclists $(4.58 \pm 0.48)$ were higher than that of male bicyclists $(4.49 \pm 0.48)$. In the light of these findings, it was found that the perceptions of female bicyclists about the spread of bicycle use were higher than that of male bicyclists.

It was found that the scores of the participants in the sub-dimensions of the scale did not show a significant difference according to the variables of education, income, marital status, age and how long an active bicyclist was.

\section{Discussion}

According to the findings, it was observed that the safety perception of bicyclist was low. It is thought that one of the main reasons for low safety perceptions of bicyclists is the lack of physical infrastructure, as found in similar studies (Balc1, Özbek, Koçak, \& Çeyiz, 2018; Çeyiz \& Koçak, 2015). It can be said that individuals feel insecure about the use of bicycles in urban traffic as the transportation policies that encourage the use of motor vehicles do not adequately cover the infrastructure works for bicycle use (bicycle lanes, secure bicycle parking areas, bicycle stations, etc.).

According to the Law in Turkey (7153 Sayılı Çevre Kanunu Ve Bazı Kanunlarda Değişiklik Yapılmasına Dair Kanun); "From 1 June 2019, it is mandatory to have bicycle paths and bicycle parking stations for transport in the new construction plans to be prepared." However, it is seen that the amendment of the law, which is thought to be prepared for the dissemination of bicycle use, covers only new construction plans. Therefore, it is possible to say that this law does not include any sanctions or incentives related to bicycle transportation activities, especially to the local administrations working in the existing settlements in metropolis. However, considering many examples of accidents that resulted in death in traffic (Taksinin çarptığı bisiklet sürücüsü öldü, Otomobil Çarpan Fransız Bisikletçi Öldü, Demir Atında Can Verdi), it is thought that revision is also needed in old settlements.

Although the security perceptions of the participants were low, the number of active bicyclists for more than 6 years was higher than the others. Although bicyclists do not feel safe on the bicycle due to the current circumstances, it can be said that they do not give up cycling due to this problem.

It was seen that the average score of female bicyclists from the security sub-dimension was lower than that of the male participants. In support of this finding; there are studies showing that female bicyclists are negatively affected by cycling because they do not feel safe in traffic (Balc1, Özbek, Koçak, \& Çeyiz, 2018; Broache, 2012; Garrard, 2003; Garrard, Rose, \& Lo, 2008). In addition, it was stated that female bicyclists encounter socio-cultural problems as well as infrastructure problems (Çeyiz \& Koçak, 2015). This situation can be explained as the reflection of gender problems in daily life. It is thought that female bicyclists are more affected than men by the negative attitudes of motor vehicle drivers in traffic, safety problems during night driving, and the inability of the bicycle to be integrated sufficiently to public transport.

In the light of the data obtained, it was seen that women are more sensitive than men in terms of the dissemination of bicycle use. This may be explained by the fact that women feel less secure on bicycle than men, and that this causes them to develop greater sensitivity to the widespread use of bicycle in society.

According to the variables of education, income, marital status, age and how long an active bicyclist has been; perceptions of security, utility and dissemination have not changed. In the light of these findings, it can be explained that situations related to social status such as age, occupation, education and income status do not change the problems that individuals face when they are cycling. It can be inferred that all individuals ride bicycles under equal conditions.

It was seen that the participants' perception of benefit from cycling and the awareness of the importance of the dissemination of cycling were high and did not change according to their social status. In the light of this finding, it can be said that all bicyclists are aware that they benefit from cycling without changing their social status. In addition, it can be said that the participants are aware of the necessity of extending the use of bicycles to the wider society.

\section{Suggestion}

Current research results were obtained from individuals actively using bicycle for various purposes (transportation, recreation, physical activity, etc.) in Turkey. In order to ensure that more individuals use bicycles, 
studies to learn the needs and expectations of individuals who do not use bicycles may contribute to the field. In this sense, in future studies, a new research can be carried out by sampling individuals not using bicycles even though their daily transportation distances are short. It can be determined whether the needs and expectations resulting from this research complement each other with the studies carried out by the local government on behalf of bicycle transportation.

In addition, experimental studies about skill changes of the individuals who learn how to ride a bicycle can be suggested.

\section{References}

Balc1, V., Özbek, O., Koçak, F., \& Çeyiz, S. (2018). Determination of the constraints of bicycle use in urban life. Journal of Human Sciences, 15(1), 35-50. https://doi.org/10.14687/jhs.v15i1.4928

Bauman, A., Rissel, C., Garrard, J., Ker, I., Speidel, R., \& Fishman, E. (2008). Cycling: Getting Australia Moving: Barriers, Facilitators and Interventions to Get More Australian Physically Active Through Cycling. Cycling Promotion Fund: Melbourne, 2008. Retrieved January 8, 2019 from https://www.researchgate.net/publication/235356404_Cycling_Getting_Australia_Moving_Barriers_Facilit ators_and_Interventions_to_Get_More_Australian_Physically_Active_Through_Cycling

Broache, A. (2012). Perspectives On Seattle Women's Decisions To Bike For Transportation. Post Graduate Thesis, University Of Washington/Department Of Urban Design And Planning, Seattle.

Buehler, R., \& Pucher, J. (2012). Walking And Cycling In Western Europe And The United States: Trends, Policies, And Lessons. TR News, 280(May-June), 34-42. Retrieved January 10, 2019, from http://onlinepubs.trb.org/onlinepubs/trnews/trnews280WesternEurope.pdf

Byrne, B. M. (2010). Structural Equation Modeling With AMOS: Basic concepts, Applications and Programming (2th ed.). Routledge Press: New York.

Çeyiz, S. (2019). How We Can Extend Cycling. Spor Yayınevi ve Kitabevi, Ankara, 2019. ISBN 978-605-69192-9-9.

Çeyiz, S., \& Koçak, F. (2015). Ankara İli’nde bisiklet kullanan bireylerin karşılaştıkları sorunlar ve çözüm önerileri. Mediterranean Journal of Humanities, V(2), 203-221. https://doi.org/10.13114/MJH.2015214567

Cirit, F. (2014). Comparison of sustainable urban transport policies and public transport systems. Uzmanlı Tezi (Dissertation). TC Kalkınma Bakanlığı (Republic of Turkey Ministry of Development).

Demir Atında Can Verdi. (2019). Bicyclist died on his horse which made of iron. Retrieved January 14, 2019, from http://www.hurriyet.com.tr/ankara/26765352.asp

Garrard, J. (2003). Healthy revolutions: promoting cycling among women. Health Promotion Journal of Australia, 14(3), 213-215. https://doi.org/10.1071/HE03213

Garrard, J., Rose, G., \& Lo, S. K. (2008). Promoting transportation cycling for women: the role of bicycle infrastructure. Preventive Medicine, 46(1), 55-59. https://doi.org/10.1016/j.ypmed.2007.07.010

Give Cycling A Push-Presto (2010). Cycling Policy Guide. Retrieved April 26, 2019, from https://www.eltis.org/sites/default/files/trainingmaterials/presto_cycling_policy_guide_electric_bicycle_en_ purple.pdf

Hendriksen, I. J., Zuiderveld, B. O. B., Kemper, H. C., \& Bezemer, P. D. (2000). Effect of commuter cycling on physical performance of male and female employees. Medicine \& Science in Sports \& Exercise, 32(2), 504. https://doi.org/10.1097/00005768-200002000-00037

Horton, D. (2006). Environmentalism and the bicycle. Environmental Politics, 15(1), 41-58. https://doi.org/10.1080/09644010500418712

International Energy Agency-CO2. (2019). Emissions from Fuel Combustion: 1971-2009. Retrieved January 5, 2019, https://www.oecd-ilibrary.org/energy/co2-emissions-from-fuel-combustion-2009_co2_fuel-2009-en-fr

Krizek, K. J., Poindexter, G., Barnes, G., \& Mogush, P. (2007). Analysing the benefits and costs of bicycle facilities via online guidelines. Planning, Practice \& Research, 22(2), 197-213. https://doi.org/10.1080/02697450701584386

Lin, J. R., \& Yang, T. H. (2011). Strategic design of public bicycle sharing systems with service level constraints. Transportation Research (part E: logistics and transportation review), 47(2), 284-294. 
https://doi.org/10.1016/j.tre.2010.09.004

Lin, J. R., Yang, T. H., \& Chang, Y. C. (2013). A hublocation inventory model for bicycle sharing system design: formulation and solution. Computers \& Industrial Engineering, 65(1), 77-78. https://doi.org/10.1016/j.cie.2011.12.006

Mert, K., \& Öcalır, E. V. (2010). Konya'da bisiklet ulaşımı: planlama ve uygulama süreçlerinin karşılaştırılması (Bicycle transportation in Konya: comparison of planning and implementation processes). METU Journal of the Faculty of Architecture, 27(1), 223-240. https://doi.org/10.4305/METU.JFA.2010.1.12

Midgley, P. (2011). Bicycle-sharing schemes: enhancing sustainable mobility in urban areas. United Nations, Department of Economic and Social Affairs, 8, 1-12. Retrieved April 23, 2019, from http://fmt.isti.cnr.it/data/media/private/adaptbp/casestudy/background-paper8-p.midgley-bicycle.pdf

O’brien, O., Cheshire, J., \& Batty, M. (2013). Mining bicycle sharing data for generating insights into sustainable transport systems. Journal of Transport Geography, 34, 262-273. https://doi.org/10.1016/j.jtrangeo.2013.06.007

O'connor, J. P., \& Brown, T. D. (2007). Real cyclists don't race: informal affiliations of the weekend

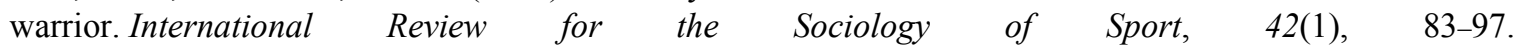
https://doi.org/10.1177/1012690207081831

Otomobil Çarpan Fransız Bisikletçi Öldü. (2019). French cyclist died after a car crash. Retrieved February 28, 2019, from https://www.cnnturk.com/yasam/otomobil-carpan-fransiz-bisikletci-oldu

Pucher, J., \& Buehler, R. (2008). Making cycling irresistible: lessons from the netherlands, denmark and germany. Transport Reviews, 28(4), 495-528. https://doi.org/10.1080/01441640701806612

Shaw, L., Poulos, R. G., Hatfield, J., \& Rissel, C. (2015). Transport cyclists and road rules: what influences the decisions they make? Injury Prevention, 21(2), 91-97. https://doi.org/10.1136/injuryprev-2014-041243

Taksinin çarptı̆̆ bisiklet sürücüsü öldü. (2019). The bicyclist died after a crash by taxi. Retrieved February 24, 2019 , https://www.cnnturk.com/yerel-haberler/izmir/konak/taksinin-carptigi-bisikletin-surucusu-oldu-1013008

Tezbaşaran, A. (1997). Likert Type Scale Development Guide. Türk Psikologlar Derneği Yayını: Ankara.

Turkish Statistical Institute. (2019). Transportation Statistics/Number of Motor Vehicles. Retrieved January 10, 2019, from http://tuik.gov.tr/PreTablo.do?alt_id=1051

Uz, V. E., \& Karaşahin, M. (2004). Bicycles for urban transport. Türkiye Mühendislik Haberleri, 429(1), 41-46. Retrieved January 20, 2019, from http://www.imo.org.tr/resimler/dosya_ekler/613d551d4160a60_ek.pdf?dergi=166

7153 Sayılı Çevre Kanunu Ve Bazı Kanunlarda Değişiklik Yapılmasına Dair Kanun (Law No. 7153 on the Amendment of Environmental Law and Some Laws). Retrieved March 24, 2019, from https://www.resmigazete.gov.tr/eskiler/2018/12/20181210-4.htm

\section{Copyrights}

Copyright for this article is retained by the author, with first publication rights granted to the journal.

This is an open-access article distributed under the terms and conditions of the Creative Commons Attribution license (http://creativecommons.org/licenses/by/4.0/). 